Original Research Paper

\title{
Potency of Kaliasem Bark (Syzygium polychephalum) Extract as Antibacterial Agent for Staphylococcus aureus
}

\author{
Ni Luh Putu Agustini ${ }^{1 *}$, Desak Putu Risky Vidika Apriyanthi ${ }^{2}$, Ayu Saka Laksmita W. ${ }^{2}$ \\ ${ }^{1}$ Program Studi Teknologi Laboratorium Medik Universitas Bali Internasional, Indoneisa \\ ${ }^{2}$ Teknologi Laboratorium Medik Universitas Bali Internasional, Indonesia
}

\author{
Article History \\ Received : September $18^{\text {th }}, 2021$ \\ Revised : October $16^{\text {th }}, 2021$ \\ Accepted : December $20^{\text {th }}, 2021$ \\ Published : January 05 $5^{\text {th }}, 2022$ \\ *Corresponding Author: \\ Ni Luh Putu Agustini, \\ Universitas Bali Internasional, \\ Denpasar, Indonesia, \\ Email:putuagustini217@gmail. \\ com \\ riskyvidika@gmail.com \\ sakalaksmita@gmail.com
}

\begin{abstract}
Nosocomial infectious diseases are caused by Staphylococcus aureus bacteria. Treatment of infection can use drugs in the form of substances produced by a microorganism in the form of antibiotics. However, the problem that often arises with antibiotics is the occurrence of resistance. Alternatives that are able to overcome the problem of antibiotic resistance against bacteria are plants that have antibacterial activity, one of which is kaliasem (Syzygium polychephalum). This study aims to determine the compounds contained in the ethanol extract of the bark of kaliasem (Syzygium polychephalum) and to determine the potential of its activitiy on the growth of Staphylococcus aureus in vitro. The bark extract of kaliasem (Syzygium polychephalum) had been carried out by using maceration method. Determination of antibacterial activity was carried out by the disc diffusion method. The ethanolic extract of the bark of kaliasem (Syzygium polychephalum) contains antibacterial compounds such as tannins, phenolics, terpenoids, alkaloids and flavonoids and the ethanolic extract of the bark of kaliasem (Syzygium polychephalum) at concentrations of $25 \%$, $50 \%, 75 \%$ and $100 \%$ can inhibit growth of Staphylococcus aureus bacteria with an average inhibition zone of $15.85 \mathrm{~mm}, 18.36 \mathrm{~mm}, 23.64 \mathrm{~mm}, 28.58$ $\mathrm{mm}$, respectively. Therefore, it can be concluded that the ethanolic extract of the bark of kaliasem (Syzygium polychephalum) contains antibacterial compounds and has the potential to inhibit the growth of Staphylococcus aureus bacteria.
\end{abstract}

Keywords: Antibacterial, Bark, Disc diffusion, Syzygium polychephalum Extract, Staphylococcus aureus.

\section{Pendahuluan}

Berdasarkan data WHO tahun 2002, $8,7 \%$ penyakit infeksi nosokomial disebabkan oleh bakteri Staphylococcus aureus. Staphylococcus aureus merupakan flora normal yang terdapat pada tubuh manusia, namun bila melebihi jumlah normalnya pada tubuh manusia mengakibatkan bakteri tersebut bersifat patogen. Masuknya bakteri Staphylococcus aureus ke dalam tubuh manusia dapat melalui luka yang terbuka, lingkungan Rumah Sakit, peralatan medis maupun non medis (Anies, 2006). Staphylococcus aureus juga dapat menimbulkan diare dan sering menyebabkan

This article is licensed under a Creative Commons Attribution 4.0 International License. penyakit dengan tanda peradangan, nekrosis dan pembentukan abses, pneumonia, endokarditis, dan septikemia serta infeksi lain (Cita, 2011).

Pengobatan infeksi dapat menggunakan obat berupa zat yang dihasilkan oleh suatu mikroorganisme. Antibiotika adalah golongan senyawa, baik alami, semi sintetis maupun sintetis, yang mempunyai khasiat membunuh atau menghambat pertumbuhan bakteri (Tan and Rahardja, 2008). Masalah yang sering muncul pada antibiotik adalah terjadinya resistensi. Tingginya resistensi meningkatkan adanya penemuan obat baru untuk menemukan produk alternatif pengganti yang 
memiliki efek samping yang kecil (Goodman and Gilman, 2008).

Alternatif yang mampu mengatasi masalah resistensi antibiotik terhadap bakteri yaitu tanaman yang memiliki khasiat obat salah satunya tumbuhan kaliasem (Syzygium polychephalum). Penelitian ini dilakukan untuk mengetahui kandungan senyawa yang terdapat pada ekstrak etanol kulit batang kaliasem (Syzygium polychephalum) serta untuk mengetahui potensi ekstrak etanol kulit batang kaliasem (Syzygium polychephalum) terhadap pertumbuhan Staphylococcus aureus secara in vitro. Penelitian ini diharapkan dapat menambah pustaka baru dalam bidang bakteriologi guna menemukan alternatif terbaik untuk mengobati penyakit yang disebabkan oleh Staphylococcus aureus, serta dapat meningkatkan pengetahuan dan keterampilan dalam mengisolasi bahan tanaman dan memberikan informasi pada masyarakat mengenai pemanfaatan kulit batang kaliasem sebagai ramuan obat dalam pengobatan infeksi bakteri akibat Staphylococcus aureus seperti dapat digunakan sebagai pengawet alami, antibiotic, antioksidan, dan lain-lain (Mujiati and Tukiran, 2017).

Hasil uji skrining awal fitokimia yang dilakukan oleh Tukiran et al. (2016), terhadap ekstrak metanol kulit batang tiga tumbuhan Syzygium, yaitu salah satunya Syzygium polychephalum, membuktikan bahwa tumbuhan ini mengandung senyawa golongan alkaloid, fenolik, flavonoid, dan tanin yang diketahui senyawa ini memiliki khasiat yang baik untuk kesehatan seperti antioksidan dan terutama antibakteri. Mujiati and Tukiran, (2017) menyatakan bahwa kulit batang kaliasem mempunyai aktivitas antioksidan dengan nilai IC50 sebesar 13,976 ppm yang termasuk kategori kuat. Aktivitas antibakteri komponen fenolik telah terbukti dapat menghambat beberapa jenis bakteri, terutama bakteri gram positif. Secara umum, bakteri gram positif lebih sensitif terhadap komponen ini. Penelitian mengenai aktivitas antibakteri terhadap kulit batang kaliasem (Syzygium polychephalum) masih jarang dilakukan. Berdasarkan uraian diatas peneliti tertarik melakukan uji aktivitas antibakteri ekstrak kulit batang tumbuhan kaliasem terhadap bakteri Staphylococcus aureus dengan hipotesis penelitian adalah senyawa aktif yang terkandung sebagai antibakteri pada ekstrak etanol kulit batang kaliasem adalah alkaloid, flavonoid, saponin, tanin, dan steroid/triterpenoid serta, ekstrak etanol kulit batang kaliasem mempunyai potensi dapat menghambat pertumbuhan Staphylococcus aureus secara in vitro.

\section{Bahan dan Metode}

Alat yang digunakan dalam penelitian ini adalah oven, rotary evaporator, blender, penggaris, waterbath, pipet ukur, dan tabung reaksi. Bahan yang digunakan dalam penelitian ini adalah sampel kulit batang kaliasem yang dicuci bersih dan dipotong kecil-kecil dan bakteri Staphylococcus aureus. Media dan reagensia yang digunakan dalam penelitian ini adalah Etanol 96\%, DMSO, $\mathrm{NaCl} 0,85 \%$, Aquadest steril, Media NA (Nutrient Agar), Media MHA (Mueler Hinton Agar), Paper disk kosong dan Paper disk yang mengandung tetraciklin.

Penelitian ini adalah penelitian eksperimental design rancangan acak lengkap (RAL), dengan melakukan percobaan untuk mengetahui daya hambat ekstrak kulit batang kaliasem terhadap pertumbuhan Staphylococcus aureus secara in vitro. Menggunakan 4 variasi konsentrasi ekstrak etanol kulit batang kaliasem, kontrol positif menggunakan antibiotik tetrasiklin serta DMSO sebagai kontrol negatif. Penentuan aktivitas antibakteri dilakukan dengan metode difusi cakram dengan media pertumbuhan Muller Hinton Agar (MHA) dengan mengukur diameter zona hambat yang dihasilkan. Variabel bebas dalam penelitian ini adalah konsentrasi ekstrak kulit batang kaliasem dengan variasi konsentrasi (b/v) 25\%, 50\% dan $70 \%$ dan $100 \%$. Skala yang digunakan adalah skala rasio. Variabel terikat dalam penelitian ini adalah pertumbuhan bakteri Staphylococcus aureus. Skala yang digunakan adalah skala rasio. Variabel pengganggu (Variabel kontrol) dalam penelitian ini adalah ketebalan media dan kekeruhan suspensi bakteri.

Tahap pertama penelitian ini adalah dilakukan determinasi tanaman kaliasem (Syzygium polychephalum). Penelitian dilanjutkan dengan pembuatan ekstrak kulit batang kaliasem dengan metode maserasi dengan 
etanol. Setelah didapatkan ekstrak kulit batang kaliasem, diujikan dengan bakteri Staphylococcus aureus yang sudah di identifikasi sebelumnya berupa pewarnaan gram dan uji biokimia. Bakteri Staphylococcus aureus yang telah diecerkan, diinokulasikan dengan teknik sebar menggunakan lidi kapas steril pada media Mueler Hinton Agar (MHA). Paper disk yang telah diresapi dengan ekstrak kulit batang kaliasem diletakkan pada masing-masing media uji. Paper disk yang mengandung tetraciklin juga diletakkan pada masing-masing media uji sebagai kontrol positif. Media diinkubasi pada suhu $37^{\circ} \mathrm{C}$ selama $1 \times 24$ jam. Zona hambat yang terbetuk di sekitar paper disk, diukur dengan satuan $\mathrm{mm}$ (millimeter) menggunakan jangka sorong. Dibandingkan zona hambat yang terbentuk dengan hasil zona hambat kontrol positif (Tetraciklin).

\section{Hasil dan Pembahasan}

\section{Ekstrak Kulit Batang Kaliasem (Syzygium polychephalum)}

Ekstrak kulit batang kaliasem yang didapatkan berwarna coklat muda. Ekstrak dibuat dengan metode maserasi menggunakan sampel kulit batang dan didapatkan berat simplisia dan berat ekstrak serta rendemen seperti yang dapat dilihat pada Tabel 1 .

Tabel 1. Rendemen Ekstrak Etanol Kulit Batang Kaliasem

\begin{tabular}{cccc}
\hline Bahan & $\begin{array}{c}\text { Berat } \\
\text { Serbuk } \\
\text { Kering }\end{array}$ & $\begin{array}{c}\text { Berat } \\
\text { Ekstrak }\end{array}$ & $\begin{array}{c}\text { Rendemen } \\
(\boldsymbol{\%})\end{array}$ \\
\hline $\begin{array}{c}\text { Kulit Batang } \\
\text { Kaliasem }\end{array}$ & $201 \mathrm{gr}$ & $2 \mathrm{gr}$ & $1,02 \%$ \\
\hline
\end{tabular}

Selanjutnya dilakukan skrining fitokimia dan kemudian diuji aktivitas antibakteri terhadap bakteri Staphylococcus aureus.

\section{Uji Fitokimia Ekstrak Etanol Kulit Batang Kaliasem (Syzygium polychephalum)}

Penentuan golongan senyawa kimia simplisia, ekstrak etanol kulit batang kaliasem dilakukan untuk mendapatkan informasi golongan senyawa metabolit sekunder yang terdapat di dalamnya. Adapun pemeriksaan yang dilakukan adalah pemeriksaan golongan senyawa saponin, tanin, fenolik, terpenoid, steroid, alkaloid dan flavonoid dengan hasil seperti tabel di bawah ini.

Tabel 2. Hasil skrining fitokimia ekstrak etanol kulit batang kaliasem

\begin{tabular}{|c|c|c|c|}
\hline No & Senyawa & $\begin{array}{c}\text { Hasil } \\
\text { Skrining } \\
\text { Ekstrak } \\
\text { Etanol }\end{array}$ & Keterangan \\
\hline 1 & Saponin & Negatif & $\begin{array}{l}\text { Terbentuk busa tidak } \\
\text { stabil lalu menghilang }\end{array}$ \\
\hline 2 & Tanin & Positif & $\begin{array}{l}\text { Perubahan warna hijau } \\
\text { kehitaman }\end{array}$ \\
\hline 3 & Fenolik & Positif & $\begin{array}{l}\text { Perubahan warna hijau } \\
\text { kehitaman }\end{array}$ \\
\hline 4 & Terpenoid & Positif & $\begin{array}{l}\text { Perubahan warna coklat } \\
\text { tua }\end{array}$ \\
\hline 5 & Steroid & Negatif & $\begin{array}{l}\text { Tidak terjadi perubahan } \\
\text { warna }\end{array}$ \\
\hline 6 & Alkaloid & Positif & $\begin{array}{l}\text { Perubahan warna orange } \\
\text { dan terbentuk endapan } \\
\text { coklat }\end{array}$ \\
\hline 7 & Flavonoid & Positif & Perubahan warna coklat \\
\hline
\end{tabular}

\section{Identifikasi Bakteri Staphylococcus aureus}

Identifikasi bakteri Staphylococcus aureus digunakan beberapa parameter uji. Parameter uji tersebut yaitu pewarnaan gram yang bertujuan untuk melihat jenis dan morfologi bakteri, hasil pengamatan dilihat pada Gambar 5.3, serta uji biokimia yang meliputi uji gula-gula, uji media NA (Nutrient Agar), uji media SIM (Sulfide Indol Motility), uji media SC (Simon Citrate) dan uji media TSIA (Triple Sugar Iron Agar), serta uji pendukung lainnya yang dilakukan adalah uji katalase. Hasil uji dapat dilihat pada Tabel 3

Tabel 3. Hasil uji identifikasi bakteri Staphylococcus aureus

\begin{tabular}{ccl}
\hline \multicolumn{1}{c}{ Uji Identifikasi } & \multicolumn{1}{c}{ Hasil } & \multicolumn{1}{c}{ Keterangan } \\
\hline Uji Biokimia (Gula-gula) & Positif & Media kuning \\
Mlukosa & Positif & Media Kuning \\
Uji media NA & Positif & Koloni putih \\
Uji media SC & Positif & $\begin{array}{l}\text { Bakteri tumbuh, } \\
\text { media berwarna } \\
\text { hijau pada dasar } \\
\text { dan biru pada } \\
\text { lereng }\end{array}$
\end{tabular}




\begin{tabular}{|c|c|c|}
\hline Uji media SIM & Positif & $\begin{array}{l}\text { Bakteri tumbuh } \\
\text { non motil }\end{array}$ \\
\hline Uji Indol & Negatif & $\begin{array}{l}\text { Tidak ada cincin } \\
\text { merah }\end{array}$ \\
\hline Uji media TSIA & Positif & $\begin{array}{l}\text { Lereng merah/ } \\
\text { dasar kuning }\end{array}$ \\
\hline Uji Katalase & Positif & $\begin{array}{l}\text { Terbentuk } \\
\text { gelembung }\end{array}$ \\
\hline Uji DNase & Positif & Koloni putih \\
\hline Uji Media BPA & Positif & Koloni Hitam \\
\hline
\end{tabular}

Pewarnaan gram yang bertujuan untuk melihat jenis dan morfologi bakteri. Hasil pewarnaan gram bakteri Staphylococcus aureus terlihat koloni berwarna ungu. Bentuk bakteri bulat bergerombol.

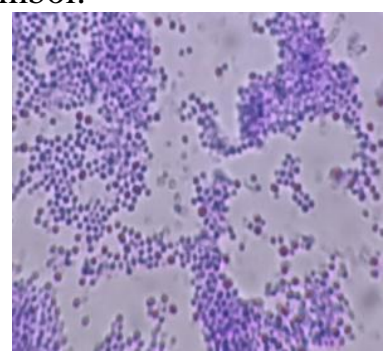

Gambar 1. Hasil Pengecatan Gram bakteri Staphylococcus aureus

\section{Uji Antibakteri Ekstrak Etanol Kulit Batang Kaliasem (Syzygium polychephalum)}

Hasil pengamatan dari uji sensitivitas dengan menggunakan metode disk diffusion atau cakram kertas dengan konsentrasi 25\%, 50\%, $75 \%$ dan $100 \%$ menggunakan tetrasiklin sebagai kontrol positif karena antibiotik ini merupakan antibiotik spektrum luas dan DMSO sebagai kontrol negatif serta digunakan untuk pelarut konsentrasi, perbandingan zona hambat antara kontrol positif dan kontrol negatif dapat dilihat pada Gambar 3. Hasil pengukuran diameter zona hambat ekstrak etanol kulit batang kaliasem (Syzygium polichepalum) terhadap bakteri Staphylococcus aureus dapat dilihat pada Tabel 4. dengan rerata dan SD yang tertera.
Tabel 4. Hasil pengukuran zona hambat ekstrak etanol kulit batang kaliasem (Syzygium polichepalum) terhadap bakteri Staphylococcus aureus

\begin{tabular}{|c|c|c|c|c|c|c|}
\hline \multirow{2}{*}{ No } & \multirow{2}{*}{$\begin{array}{l}\text { Konsent } \\
\text { rasi }\end{array}$} & \multicolumn{4}{|c|}{ Diameter (mm) } & \multirow{2}{*}{$\begin{array}{c}\text { Rerata } \pm \\
\text { SD } \\
(\mathbf{m m})\end{array}$} \\
\hline & & $\mathbf{I}$ & II & III & IV & \\
\hline \multirow[t]{2}{*}{1} & Kontrol & & & & & \\
\hline & Negatif & 0 & 0 & 0 & 0 & $0 \pm 0,00$ \\
\hline \multirow[t]{2}{*}{2} & Kontrol & 32,6 & 31,4 & 32,8 & & $32,54 \pm$ \\
\hline & Positif & 5 & 8 & 5 & 33,2 & 0,75 \\
\hline \multirow[t]{2}{*}{3} & $25 \%$ & 19,4 & 13,7 & 14,8 & 15,4 & $15,85 \pm$ \\
\hline & & 0 & 8 & 0 & 3 & 2,46 \\
\hline \multirow[t]{2}{*}{4} & $50 \%$ & 20,5 & & 17,5 & 16,7 & $18,36 \pm$ \\
\hline & & 3 & 18,6 & 8 & 3 & 1,64 \\
\hline \multirow[t]{2}{*}{5} & $75 \%$ & 24,3 & 25,4 & & 20,2 & $23,64 \pm$ \\
\hline & & 8 & 3 & 24,5 & 5 & 2,31 \\
\hline \multirow[t]{2}{*}{6} & $100 \%$ & 28,2 & 30,7 & 28,8 & 26,3 & $28,58 \pm$ \\
\hline & & 8 & 8 & 8 & 8 & 1,81 \\
\hline
\end{tabular}

Hasil zona hambat yang didapatkan dalam penelitian ini seperti yang dilihat pada Gambar 2 terlihat terbentuk zona bening dengan besar zona yang bervariasi. Semakin besar konsentrasi semakin besar pula zona hambat yang terbentuk dengan pertumbuhan bakteri yang merata di samping zona hambat.

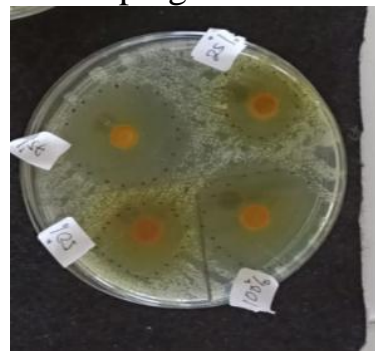

Gambar 2. Hasil zona hambat ekstrak etanol kulit batang kaliasem (Syzygium polichepalum) terhadap bakteri Staphylococcus aureus.
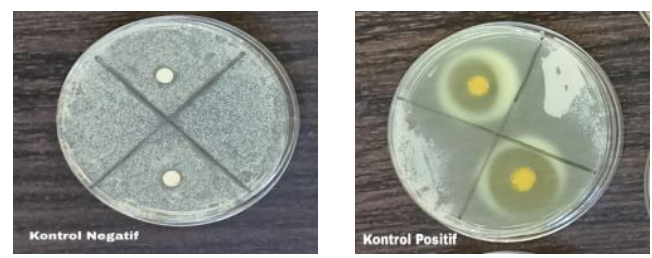

Gambar 3. Hasil zona hambat antara kontrol negatif dan kontrol positif 
Hasil Analisis Data Ekstrak Etanol Kulit Batang Kaliasem (Syzygium polichepalum) terhadap Bakteri Staphylococcus aureus

Tabel 5. Hasil analisis data dengan software SPSS Versi 25

\begin{tabular}{cclcc}
\hline $\begin{array}{c}\text { Perlakua } \\
\mathbf{n}\end{array}$ & $\begin{array}{c}\text { Mean } \pm \text { SD } \\
(\mathbf{m m})\end{array}$ & $\begin{array}{c}\text { Normal } \\
\text { itas }(\mathbf{p})\end{array}$ & $\begin{array}{c}\text { Homog } \\
\text { enitas } \\
(\mathbf{p})\end{array}$ & $\begin{array}{c}\text { ANO } \\
\text { VA } \\
(\mathbf{s i g})\end{array}$ \\
\hline Kontrol & & $0,365>$ & & \\
positif & $32,54 \pm 0,75$ & 0,05 & & \\
Kontrol & & $0,000<$ & 0,116 & 0,000 \\
negatif & $0 \pm 0,00$ & 0,05 & $>0,05$ & $<0,05$ \\
$25 \%$ & & $0,284>$ & & \\
& $15,85 \pm 2,46$ & 0,05 & & \\
$50 \%$ & & $0,798>$ & & \\
& $18,36 \pm 1,64$ & 0,05 & & \\
$75 \%$ & & $0,106>$ & & \\
& $23,64 \pm 2,31$ & 0,05 & & \\
$100 \%$ & & $0,956>$ & \\
& $28,58 \pm 1,81$ & 0,05 & & \\
\hline
\end{tabular}

\section{Pembahasan}

Tanaman kaliasem yang digunakan untuk penelitian didapatkan di Desa Sibetan, Kecamatan Bebandem, Kabupaten Karangasem, Bali. Tanaman ini kemudian diidentifikasi dengan melakukan determinasi di Lembaga Ilmu Pengetahuan Indonesia (LIPI) Balai Konservasi Tumbuhan Kebun Raya "Eka Karya” Bali yang bertempat di Desa Candikuning, Kecamatan Baturiti, Kabupaten Tabanan, Bali. Determinasi dari suatu tanaman bertujuan untuk mengetahui kebenaran identitas tanaman tersebut, apakah tanaman tersebut benar-benar tanaman yang diinginkan. Dengan demikian kesalahan dalam pengumpulan bahan yang akan diteliti dapat dihindari. Hasil determinasi menunjukkan bahwa sampel yang digunakan merupakan Syzygium polychephalum dari famili Syzygium.

Penelitian dilanjutkan dengan pembuatan ekstrak kulit batang kaliasem (Syzygium polychephalum). Bagian pohon kaliasem yang digunakan untuk pembuatan ekstrak adalah bagian kulit batang. Batang kaliasem memiliki diameter mencapai $50 \mathrm{~cm}$. Kulit batang kaliasem berwarna coklat muda. Kulit batang diambil dari bagian permukaan hingga mencapai kurang lebih $1 \mathrm{~cm}$ dari permukaan batang. Kulit batang kemudian dibersihkan dan dipotong kecil-kecil lalu dikeringkan dalam suhu ruangan sekitar 7 hari hingga kulit batang kering sempurna (Nurmalasari et al., 2016).
Penelitian selanjutnya dilakukan uji fitokimia pada sampel. Uji fitokimia merupakan cara untuk mengidentifikasi bioaktif yang belum tampak melalui suatu tes atau pemeriksaan yang dapat dengan cepat memisahkan antara bahan alam yang memiliki kandungan fitokimia tertentu dengan bahan alam yang tidak memiliki kandungan fitokimia tertentu. Metode skrining fitokimia dilakukan dengan melihat reaksi pengujian warna dengan menggunakan suatu pereaksi warna. Hal penting yang berperan penting dalam skrining fitokimia adalah pemilihan pelarut dan metode ekstraksi (Kristianti et al., 2008). Skrining fitokimia serbuk simplisia dan sampel dalam bentuk basah meliputi pemeriksaan kandungan senyawa saponin, tanin, fenolik, terpenoid, steroid, alkaloid, dan flavonoid.

Kandungan saponin pada kulit batang kaliasem (Syzygium polichephalum) memiliki kualitas yang dapat bekerja melawan sel kanker. Saponin memiliki efek antioksidan dan dapat langsung menjadi racun bagi sel kanker. Selaput sel kanker memiliki senyawa tipe kolesterol. Saponin mampu mengikat senyawa ini dan mengganggu proliferasi sel kanker (Wijaya, 2000). Pada uji saponin menunjukkan hasil negatif. Hasil positif menunjukkan busa stabil. Pada sampel hasil busa tidak stabil dan menghilang sehingga kesimpulan hasil yang didapat sampel kulit batang kaliasem tidak mengandung senyawa saponin. Pada penelitian Nurmalasari et al. (2016), menyatakan bahwa hasil uji skrining fitokimia kandungan saponin pada tanaman kaliasem (Syzygium polichephalum) terhadap simplisia ekstrak daging buah dan biji buah juga menunjukkan hasil negatif.

Tanin memiliki beberapa sifat seperti astringen, antidiare, antibakteri dan antioksidan. Tanin pada kulit batang kaliasem (Syzygium polichephalum) berperan sebagai pendenaturasi protein serta mencegah proses pencernaan bakteri. Mekanisme kerjanya dalam menghambat bakteri dilakukan dengan cara mendenaturasi protein dan merusak membran sel bakteri dengan cara melarutkan lemak yang terdapat pada dinding sel. Senyawa ini mampu melakukan migrasi dari fase cair ke fase lemak. Terjadinya kerusakan pada membran sel mengakibatkan terhambatnya aktivitas dan biosintesa enzimenzim spesifik yang diperlukan dalam reaksi 
metabolisme dan kondisi ini yang pada akhirnya menyebabkan kematian pada bakteri (Naiborhu, 2002). Pada uji tanin menunjukkan hasil positif. Pada sampel kulit batang kaliasem menunjukkan perubahan warna menjadi warna hijau kehitaman sehingga sampel mengandung senyawa tanin. Pada penelitian Tukiran et al. (2016), menyatakan bahwa skrining fitokimia pada kulit batang tumbuhan syzygium menggunakan pelarut metanol, hasilnya menunjukkan tanaman Syzygium polychephalum mengandung senyawa tanin.

Senyawa fenolik memiliki sifat anti mikroba yang kuat dan salah satu penggunaan paling awal adalah sebagai antiseptik. Senyawa fenolik biasa digunakan dalam larutan berair untuk mensterilkan luka dan peralatan bedah, sangat meningkatkan tingkat kelangsungan hidup pasien yang menjalani operasi (Saragih dan Arsita, 2019). Pada uji fenolik menunjukkan hasil positif. Hasil positif menunjukkan larutan berubah warna menjadi warna hijau kehitaman. Pada sampel kulit batang kaliasem dinyatakan mengandung senyawa fenolik karena larutan berubah warna menjadi warna hijau kehitaman. Pada genus Syzygium telah banyak ditemukan senyawa golongan fenolik baik berupa flavonoid maupun golongan polifenol. Berdasarkan pengujian awal fitokimia pada tiga tumbuhan Syzygium, yaitu kaliasem, salam dan jambu bol ketiganya positif mengandung senyawa fenolik (Tukiran et al., 2016)

Triterpenoid memiliki kesamaan dan kemungkinan hubungan biogenesis dengan steroid. Beberapa aktivitas fisiologis yang menarik ditunjukkan oleh beberapa triterpenoid. Senyawa ini merupakan komponen aktif dalam tanaman obat yang telah digunakan untuk diabetes, gangguan menstruasi, luka gigitan ular, gangguan kulit, kerusakan hati dan malaria. (Saragih dan Arsita, 2019). Pada uji terpenoid hasil menunjukkan hasil positif dan pada uji steroid menunjukkan hasil negatif. Hasil positif terpenoid menunjukkan warna merah hingga coklat pada larutan, sedangkan hasil positif menunjukkan warna biru pada larutan. Pada sampel kulit batang kaliasem dinyatakan mengandung senyawa terpenoid karena larutan berubah warna menjadi warna merah kecoklatan. Sedangkan senyawa steroid tidak terkandung karena larutan tidak menunjukkan perubahan warna.
Alkaloid merupakan senyawa yang termasuk ke dalam morfin, kokain, atropin, kikine dan kafein. Senyawa ini banyak digunakan dalam obat sebagai analgesik atau anastetik. Pada uji alkaloid hasil menunjukkan hasil positif. Hasil positif menunjukkan terbentukannya endapan coklat keemasan. Pada sampel kulit batang kaliasem dinyatakan mengandung senyawa alkaloid karena terdapat endapan berwarna coklat keemasan dan larutan berubah berwarna oranye. Beberapa penelitian berkaitan dengan skrining fitokimia genus Syzygium adalah ekstrak metanol kulit batang tiga tumbuhan genus Syzygium, yakni Syzygium polychephalum (gowok), Syzygium polyanthum (salam) dan Syzygium malaccense (jambu bol) positif mengandung senyawa golongan alkaloid (Tukiran and Hafizh, 2020).

Flavonoid memiliki beberapa fungsi kesehatan. Fungsi flavonoid diantaranya sebagai pengaturan tanaman, pengaturan fotosintesis, anti mikroba dan kerja antivirus dan flavonoid digunakan dalam pengobatan tradisional (Sjahid 2008). Pada uji flavonoid hasil menunjukkan hasil positif. Hasil positif menunjukkan warna larutan berubah menjadu warna coklat. Pada sampel kulit batang kaliasem dinyatakan mengandung senyawa flavonoid dengan larutan berwarna coklat. Penelitian kemudian dilanjutkan dengan identifikasi bakteri Staphylococcus aureus. Nava et al. (2010), membuktikan adanya mikroorganisme Staphylococcus aureus dan Arcanobacterium pyogenes di vagina normal, selain itu vagina yang mengalami peradangan juga ditemukan Staphylococcus sp. Penelitian oleh Ajala et al. (2011), menyatakan bahwa adanya Staphylococcus $s p$. pada kambing betina di Turki.

Identifikasi bakteri dilakukan dengan pengecatan gram terlebih dahulu. Pewarnaan Gram adalah teknik pewarnaan diferensial yang memisahkan bakteri menjadi dua kelompok yaitu Gram positif dan Gram negatif. Bakteri Gram positif mempertahankan zat warna kristal violet karenanya tampak ungu tua sedangkan bakteri Gram negatif kehilangan kristal violet ketika dicuci dengan alkohol dan waktu diberi pewarna tandingan dengan warna merah safranin tampak bewarna merah (Zubaidah, 2006). Menurut Purves dan Sadava (2003), menyatakan bahwa perbedaan warna tersebut dikarenakan perbedaan 
ketebalan dinding peptidoglikan bakteri, bakteri Gram negatif memiliki peptidoglikan lebih tipis dibandingkan dengan bakteri Gram positif. Perbedaan ketebalan dinding ini mengakibatkan perbedaan kemampuan afinitas dengan pewarna Gram.Pengecatan gram yang telah dilakukan dalam penelitian ini diambil koloni bakteri pada media NA (Nutrient Agar) berwarna putih ukuran kecil. Pada pengamatan mikroskop terlihat bakteri berbentuk bulat dengan warna ungu kemerahan. Susunan sel yang terlihat bergerombol. Ini menunjukkan bahwa bakteri yang diidentifikasi merupakan bakteri gram positif. Selanjutnya dilakukan uji biokimia dengan uji mannitol dan uji glukosa.

Staphylococcus aureus mampu memfermentasi manitol serta mampu memfermentasi glukosa menghasilkan asam laktat (Todar, 2005). Uji fermentasi larutan manitol yang positif pada Staphylococcus aureus yaitu terjadi perubahan warna medium menjadi kuning menunjukan bahwa Staphylococcus aureus merubah manitol yang menghasilkan asam laktat sehingga dapat mengubah $\mathrm{pH}$ medium menjadi asam (Sari, 2003). Terjadi perubahan warna media dari hijau menjadi kuning karena dapat memfermentasikan mannitol. Sebagian besar mikroorganisme memperoleh energi dari substrat berupa karbohidrat yang selanjutnya difermentasi menghasilkan asam-asam organik (seperti asam laktat dan asetat) dengan disertai atau tidak disertai pembentukan gas (Tambayong, 2009).

Media juga ditumbuhkan pada media BPA (Baird Parker Agar) yang merupakan media selektif untuk bakteri Staphylococcus aureus. Deteksi adanya Staphylococcus aureus dilihat dari pertumbuhan koloni pada media Baird Parker Agar (BPA) dengan ciri koloni berwarna hitam dikelilingi zona bening. Identifikasi Staphylococcus aureus menggunakan media Baird Parker Agar yang mengandung litium klorida dan telurit untuk menghambat pertumbuhan bakteri lain, sedangkan kandungan piruvat dan glisin dimaksudkan untuk mendukung pertumbuhan Staphylococcus aureus. Adanya reduksi tellurite menjadi tellurium menyebabkan koloni Staphylococcus aureus berwana hitam. Egg-yolk yang ditambahkan akan mengalami proteolisis dan lipolisis sehingga terbentuk daerah bening di sekitar koloni berbentuk cincin (Puspadewi et al., 2017).

Identifikasi selanjutnya dilakukan uji katalase. Uji katalase penting untuk membedakan Streptococcus dengan Staphylococcus. Uji katalase digunakan untuk mengetahui aktivitas katalase pada bakteri yang diuji. Kebanyakan bakteri memproduksi enzim katalase yang dapat memecah $\mathrm{H}_{2} \mathrm{O}_{2}$ menjadi $\mathrm{H}_{2} \mathrm{O}$ dan $\mathrm{O}_{2}$. Hidrogen peroksida terbentuk sewaktu metabolisme aerob, sehingga mikroorganisme yang tumbuh dalam lingkungan aerob dapat menguraikan zat toksik tersebut. Penentuan adanya katalase diuji dengan larutan $\mathrm{H}_{2} \mathrm{O}_{2} 3 \%$ pada bakteri Staphylococcus aureus yang telah dibiakkan dalam media NA. Pada bakteri yang bersifat katalase positif terlihat pembentukan gelembung di dalam tabung reaksi (Waluyo, 2005).

Penelitian dilanjutkan dengan uji aktivitas antibakteri ekstrak etanol kulit batang kaliasem (Syzygium polichephalum). Uji aktivitas antibakteri terhadap ekstrak etanol kulit batang kaliasem (Syzygium polichephalum) yang dilakukan dengan metode difusi cakram kemudian diujikan pada medium MHA. Penggunaan medium MHA sebagai media pengujian dikarenakan medium MHA mengandung starch (tepung padi) yang berfungsi untuk menyerap racun yang dikeluarkan bakteri sehingga tidak mengganggu antibiotik. (Wahyuni, 2020).

Adanya perbedaan diameter zona hambat pertumbuhan bakteri Staphylococcus aureus yang dipengaruhi oleh berbagai konsentrasi ekstrak kulit batang kaliasem (Syzygium polichephalum) dikarenakan kadar kandungan zat antimikroba yang berbeda pada masingmasing konsentrasi. Konsentrasi $100 \%$ pada penelitian ini merupakan konsentrasi tertinggi yang paling baik dalam aktif zat antimikroba pada konsentrasi $100 \%$ memiliki kadar kandungan yang sangat besar daripada konsentrasi yang lainnya (Wahyuni, 2020). Hal ini bisa terjadi karena peningkatan kandungan ekstrak pada setiap peningkatan konsentrasi sehingga kandungan zat aktif yang dapat menghambat pertumbuhan bakteri juga meningkat. Pada penelitian sebelumnya yang telah dilakukan oleh Tammi et al. (2018), menyatakan bahwa dengan menggunakan ekstrak etanol daun salam terhadap 
Staphylococcus aureus dengan menggunakan metode kirby bauer disc diffusion, dengan konsentrasi 20\%, 40\%, 60\%, 80\%, dan $100 \%$. Pada bakteri Staphylococcus aureus, daya antibakteri terbesar juga ditemukan pada tingkat konsentrasi $100 \%$ yaitu $22,75 \mathrm{~mm}$

Pada perlakuan kontrol digunakan DMSO sebagai kontrol negatif dan tetraciklin sebagai kontrol positif. Perlakuan kontrol negatif setelah pengamatan yaitu tidak terdapat daerah bening yang muncul disekitar kertas cakram sehingga perlakuan kontrol negatif ini tidak memberikan pengaruh terhadap diameter zona hambat bakteri Staphylococcus aureus. Sedangkan perlakuan kontrol positif menggunakan antibiotik yaitu tetraciklin untuk membandingkan efek antibakteri antara tetraciklin dengan ekstrak kulit batang kaliasem (Syzygium polichephalum). Pemilihan tetraciklin sebagai kontrol karena merupakan antibiotik spektrum luas. Setelah dilakukan pengamatan, tetraciklin mampu menghasilkan zona hambat, hal ini ditandai dengan munculnya daerah bening disekitar kertas cakram. Rata-rata diameter zona hambat yang dihasilkan oleh tetraciklin yaitu $32,5 \mathrm{~mm}$.

Dari uji sensitivitas ekstrak kulit batang kaliasem (Syzygium polichephalum) terhadap bakteri Staphylococcus aureus pada tabel 5.4 didapatkan rata-rata zona hambat ekstrak dari konsentrasi $25 \%$ yakni $15,85 \mathrm{~mm}, 50 \%$ yakni $18,36 \mathrm{~mm}, 75 \%$ yakni $23,64 \mathrm{~mm}$ dan $100 \%$ yaitu $28,58 \mathrm{~mm}$ dalam 4 replikasi sementara untuk kontrol positif yang menggunakan tetraciklin didapatkan yakni 32,5 mm. Pada penelitian yang dilakukan oleh Poeloengan et al. (2007), menyatakan bahwa uji daya hambat ekstrak etanol kulit batang bungur terhadap bakteri Staphylococcus aureus juga menggunakan kontrol positif berupa tetraciklin dengan rata-rata diameter zona hambat yaitu $30 \mathrm{~mm}$. Untuk kontrol negatif menggunakan DMSO yakni menghasilkan zona hambat $0 \mathrm{~mm}$ dan dari hasil tersebut pula didapatkan bahwa konsentrasi ekstrak kulit batang kaliasem (Syzygium polichephalum) yang paling baik atau yang besar daya hambatnya yaitu pada konsentrasi $100 \%$ sebesar 30,78 mm pada plate MHA 2 sedangkan yang paling rendah pada konsentrasi $25 \%$ sebesar 13,78 mm pada MHA 2, sehingga didapatkan bahwa semakin besar konsentrasi ekstrak yang digunakan maka besar pula zona hambat yang akan terbentuk namun ketika konsentrasinya berkurang maka daya hambatnya akan semakin menurun.

Hasil data penelitian diolah dengan melakukan analisis data. Analisis data dilakukan dengan menggunakan uji One Way ANOVA. Sebelum dilakukan perhitungan, perlu dipenuhi beberapa syarat wajib untuk menggunakan uji One Way Anova yaitu, uji normalitas dan uji homogenitas variansi. Uji normalitas data bertujuan untuk mengetahui apakah data terdistribusi normal atau tidak. Penelitian ini menggunakan uji Saphiro-Wilk sebagai uji normalitas data dikarenakan jumlah sampel kurang dari 50 sampel. Data hasil uji normalitas dapat dilihat pada tabel 5.6. Berdasarkan tabel dapat diketahui hasil uji normalitas pada kolom Saphiro-Wilk nilai probabilitas data yang didapatkan yaitu pada tetraciklin sebagai kontrol positif memiliki nilai probabilitas $(\mathrm{p})=0,365$, konsentrasi $25 \%$ memiliki nilai probabilitas $(\mathrm{p})=0,284$, konsentrasi $50 \%$ memiliki nilai probabilitas $\quad(\mathrm{p})=0,798$, konsentrasi $75 \%$ memiliki nilai probabilitas $(\mathrm{p})=0,106$ dan untuk konsentrasi $100 \%$ memiliki nilai probabilitas $(p)=0,956$. Kontrol negatif tidak dimasukkan dalam pengolahan data ini karena hasilnya statis yaitu 0 sehingga dihilangkan secara otomatis oleh sistem. Nilai probabilitas dapat dikatakan terdistribusi normal apabila $\mathrm{p}>0,05$, sehingga semua data pada tabel terdistribusi normal.

Uji selanjutnya yang dilakukan adalah uji homogenitas variansi. Uji homogenitas variansi data bertujuan untuk menguji apakah setiap kelompok perlakuan mempunyai data yang homogen atau tidak dan uji homogenitas variansi merupakan syarat kedua yang harus dipenuhi apabila ingin melakukan pengujian data yang menggunakan uji One Way Analysis of Variance (ANOVA). Hasil uji homogenitas variansi yang didapat dapat dilihat pada Tabel 5.7 terlihat bahwa nilai probabilitas $(\mathrm{p})=0,116$ dimana nilai p> 0,05 sehingga dapat disimpulkan bahwa data yang di dapat memiliki variansi yang sama atau homogen. Dengan demikian syarat-syarat untuk melakukan pengujian data dengan menggunakan uji One Way ANOVA sudah terpenuhi dan dapat dilanjutkan ke tahap selanjutnya yaitu uji One Way Analysis of Variance (ANOVA).

Uji One Way Analysis of Variance (ANOVA) merupakan cara untuk mengetahui apakah terdapat daya antibakteri ekstrak etanol kulit batang kaliasem (Syzygium polichephalum) 
terhadap pertumbuhan bakteri Staphylococcus aureus. Berdasarkan tabel 5.8 pada Uji One Way Analysis of Variance (ANOVA) didapatkan hasil dimana nilai probabilitas $(\mathrm{p})=0,000$ atau nilai (p) < 0,05 sehingga $\mathrm{H}_{\mathrm{o}}$ ditolak dan $\mathrm{H}_{1}$ diterima yaitu ekstrak etanol kulit batang kaliasem (Syzygium polichephalum) memiliki daya antibakteri terhadap pertumbuhan bakteri Staphylococcus aureus. Uji One Way Analysis of Variance (ANOVA) merupakan uji yang digunakan untuk melihat ada tidaknya daya antibakteri pada setiap kelompok, tetapi tidak dapat digunakan untuk melihat seberapa besar signifikansi perbedaan rerata daya hambat tiap kelompok perlakuan sehingga dilakukan uji selanjutnya yaitu Uji LSD (Trisia et al., 2018).

Signifikansi perbedaan rerata daya hambat tiap kelompok perlakuan pada penelitian ini diuji dengan uji LSD (Least Significance Difference). Hasil Uji LSD dapat dilihat pada Tabel 5.9. Pada tabel menunjukkan jika data memiliki nilai $\mathrm{p}<$ 0,05 berarti data tersebut signifikan dengan konsentrasi lain. Jika $\mathrm{p}>0,05$, maka data tersebut tidak signifikan dengan konsentrasi lain. Uji Post-Hoc menunjukkan diameter zona hambat bakteri Staphylococcus aureus. Untuk kontrol positif memiliki perbedaan bermakna dengan konsentrasi lain. Untuk konsentrasi ekstrak 25\% tidak memiliki perbedaan bermakna dengan konsentrasi $50 \%$, tetapi terdapat perbedaan bermakna pada konsentrasi $75 \%, 100 \%$, kontrol positif, dan kontrol negatif. Untuk konsentrasi $50 \%$, tidak memiliki perbedaan bermakna dengan konsentrasi 25\%, tetapi berbeda bermakna dengan konsentrasi $75 \%, 100 \%$, kontrol positif, dan kontrol negatif. Konsentrasi $75 \%$ memiliki perbedaan bermakna dengan konsentrasi 25\%, 50\%, 100\%, dan seluruh kontrol. Sedangkan konsentrasi $100 \%$ memiliki perbedaan bermakna dengan semua konsentrasi, baik $25 \%, 50 \%, 75 \%$, dan seluruh kontrol. Secara keseluruhan pada penelitian ini pengulangan dalam berbagai konsentrasi menunjukkan aktivitas antibakteri dengan terbentuknya zona hambat. Hal ini membuktikan hipotesis dalam penelitian ini bahwa ekstrak etanol kulit batang kaliasem (Syzygium polichephalum) menghambat pertumbuhan bakteri Staphylococcus aureus dengan metode difusi cakram (Trisia et al., 2018).

\section{Kesimpulan}

Berdasarkan hasil penelitian uji antibakteri dari ekstrak etanol kulit batang kaliasem (Syzygium polichephalum) terhadap pertumbuhan bakteri Staphylococcus aureus maka dapat disimpulkan dari hasil uji fitokimia secara kualitatif telah terbukti bahwa ekstrak etanol kulit batang kaliasem (Syzygium polichephalum) mengandung senyawa antibakteri yaitu alkaloid, flavonoid, tanin, fenolik dan terpenoid. Ekstrak etanol kulit batang kaliasem (Syzygium polichephalum) juga memiliki potensi aktivitas antibakteri dengan daya hambat pertumbuhan bakteri Staphylococcus aureus terbesar pada konsentrasi $100 \%$ dengan rata-rata diameter zona hambat adalah $22,75 \mathrm{~mm}$.

\section{Ucapan terima kasih}

Pada kesempatan ini penulis mengucapkan terima kasih yang sebesar-besarnya kepada pihak - pihak yang telah banyak membantu dalam penyusunan jurnal ini. Dalam penyusunan jurnal penulis didanai secara mandiri yaitu oleh orang tua penulis sendiri.

\section{References}

Ajala, O.O., A.O. Okunlade, O.F. Ogundare, Adekemi, A. Adeshoga, A.M. Afolabi, and R.E. Oludare (2011). "The prevalence and identification of the bacteria associated with caprine vulvovaginitis in ibadan". J. Anim. Vet. Adv. 14(8):11151118 .

Anies (2006). Waspada Ancaman Penyakit Tidak Menular. Jakarta: PT.Elex Media Komputindo.

Cita, Y. P. (2011). Bakteri Salmonella Typhi Dan demam tifoid. Jurnal Kesehatan Masyarakat. 6 (1).

Goodman and Gilman (2008). Manual Farmakologi dan Terapi. Jakarta: McGraw-Hill

Ibrahim, J. (2017). “Tingkat Cemaran Bakteri Staphylococcus aureus Pada Daging Ayam Yang Dijual Di Pasar Tradisional Makassar". Makassar: Jurusan Ilmu 
Peternakan Fakultas Sains Dan Teknologi Universitas Islam Negeri Alauddin Makassar.

Laila, N. H., Wiwiek, T., Ratih, N. P., Sri, C., Maya, N. Y., and Prima, A. W. (2019). "Isolasidan Identifikasi Staphylococcus aureus pada Susu Kambing Peranakan Etawah Penderita Mastitis Subklinis di Kelurahan Kalipuro, Banyuwangi”. Jurnal Medik Veteriner. 2 (2): 76-82.

Mujiati and Tukiran (2017). Uji Aktivitas Antioksidan Dari Ekstrak Metanol Kulit Batang Tumbuhan Gowok (Syzygium Polychephalum) Activity Antioxidant Test from Methanol Extract of The Stem Bark Gowok Plant (Syzygium polychephalum). UNESA Journal of Chemistry. 6 (3).

Naiborhu, P.E. (2002). "Ekstraksi dan Manfaat Ekstrak Mangrove (Sonneratia alba dan Sonneratia caseolaris) Sebagai Bahan Alami Antibakterial pada Patogen Udang Windu, Vibrio harveyi”. [Tesis]. Bogor: Sekolah Pascasarjana IPB.

Nava, S.Z., J.B. Ocando, and J. Nava (2010). "Normal bacterial flora from vaginas of Criollo Limonero cows". Am. J. Vet. Res. 43(1):291-294.

Nurmalasari, T., Zahara, S., Arisanti, N., Mentari, P., Nurbaeti, Y., Lestari, T and Rahmiyani, I. (2016). "Uji Aktivitas Antioksidan Ekstrak Buah Kupa (Syzygium Polychephalum) Terhadap Radikal Bebas Dengan Metode DPPH". Jurnal Kesehatan Bakti Tunas Husada. 16 (1).

Poeloengan, M., Andriani, Susan, M. N., K. Iyep, \& H. Mirza (2007). "Uji Daya Antibakteri ekstrak etanol kulit batang bungur (Largerstoremia speciosa Pers) terhadap Staphylococcus aureus dan Escherichia coli secara in vitro". Seminar Nasional Teknologi Peternakan dan Veteriner. 776 782.
Purves, W.K. and D.E. Sadava (2003). "Life the Science of Biology. 7 th ed". New York: Sinauer Associates Inc.

Puspadewi, R., P. “Adirestuti \& A. Abdulbasith (2017). Deteksi Staphylococcus aureus dan Salmonella Pada Jajanan Sirup". Jurnal Ilmiah Manuntung, 3(1): 26-33.

Saragih, D.E \& E.V. Arsita (2019). "Kandungan fitokimia Zanthoxylum acanthopodium dan potensinya sebagai tanaman obat di wilayah Toba Samosir dan Tapanuli Utara, Sumatera Utara". Jurnal Pros Semnas Masy Biodiv Indon. 5(1): 71-76

Sari, R.W. (2003). "Pengaruh Pemberian Gerusan Daun Sirih Hitam, Gerusan Daun Sirih Jawa dan Oksitetrasiklin secara Topikal terhadap Lama dan Waktu Kesembuhan Luka Infeksi S. aureus pada Tikus Putih". Skripsi. Surabaya: Fakultas Kedokteran Hewan. Universitas Airlangga.

Sarudji, S., Chusniati, S., Tyasningsih, W and Handijatno, D. (2017). "Petunjuk Praktikum Penyakit Infeksius Progam S-1 Kedokteran Hewan”. Airlangga: Departemen Pendidikan Nasional Fakultas Kedokteran Hewan Universitas Airlangga.

Sjahid LR. (2008). "Isolasi dan Identifikasi Flavonoid dari Daun Dewandaru (Eugenia Uniflora L.)[Skripsi]". Surakarta: Universitas Muhamadiah Surakarta.

Tambayong, J. (2009). "Mikrobiologi untuk Keperawatan.” Jakarta: Widya Medika.

Tammi, A., E. Apriliana, T. U., Sholeha, and M. R., Ramadhian (2018). "Potensi Ekstrak Daun Salam (Syzygium polyanthum [Wight.] Walp.) sebagai Antibakteri terhadap Staphylococcus aureus secara In Vitro. Jounal Agromedicine Unila." 5(2): 562-566.

Tan, H. T and Raharja, K. (2008). Obat-obat Penting. Edisi 6. Jakarta: Gramedia. 
Tiwari, P., B. Kumar, M. Kaur, G. Kaur, and H. Kaur (2011). "Phytochemical Screening and Extraction: A Review. International Pharmaceutica Sciencia." 1(1): 98-106.

Todar, K. (2005). "Salmonella and Salmonellosis. Todar's Online Textbook of Bacteriology". Wisconsin: University of Wisconsin-Madison Department of Bacteriology.

Toelle, N. N and Lenda, V. (2014). "Identifikasi dan Karakteristik Staphylococcus Sp. dan Streptococcus Sp. dari Infeksi Ovarium Pada Ayam Petelur Komersial". Journal Ilmu Ternak. 1(7): 32-37.

Trisia, A., R. Philyria and A. N., Toemon (2018). "Uji Antibakteri Daun Kalanduyung terhadap Staphylococcus aureus". Anterior Jurnal. 17(2): 136-143.

Tukiran and I. A. Hafizh (2020). "Skrining Fitokimia Ekstrak Diklorometana Kulit Batang Tumbuhan Jambu Semarang (Syzygium samarangense)". UNESA Journal of Chemistry. 9(1): 49-53

Tukiran, Wardana, A. P., Nurlaila, E., Santi, A. M and Hidayati, N. (2016). "Analisis Awal Fitokimia Pada Ekstrak Metanol Kulit Batang Tumbuhan Syzygium (Myrtaceae) "Surabaya: Jurusan Kimia FMIPA Universitas Negeri Surabaya.

Wahyuni, A. (2020). "Pengaruh Ekstrak Metanol Kulit Batang Kayu Manis (Cinnamomum Burmannii) Terhadap Pertumbuhan Bakteri Staphylococcus aureus". Skripsi Fakultas Kedokteran Dan Ilmu Kesehatan. Makassar: Universitas Muhammadiyah.

Waluyo, L. (2005). "Mikrobiologi Umum. Edisi ke-2." Malang: Universitas Muhamadiyah Malang.

Wijaya, C.H. (2000). "Isolasi dan identifikasi senyawa trigeminal aktif buah andaliman (Zanthoxylum acanthopodium DC)". Hayati J. Biosci. 7(1): 91- 95.
Zubaidah, K. (2006). "Mikrobiologi Umum". Malang: Universitas Brawijaya. 